\title{
Eosinophilic Ascites: Uncommon Presentation of Eosinophilic Gastroenteritis in a Young Adult Male
}

\author{
Luís Carvalho Lourenço David Valadas Horta Jorge Reis \\ Gastroenterology Department, Hospital Professor Doutor Fernando Fonseca, Amadora, Portugal
}

Keywords

Eosinophilic gastroenteritis · Ascites · Abdominal pain

\section{Ascite Eosinofílica: Forma de Apresentação Incomum de Gastroenterite Eosinofílica num Adulto Jovem}

\section{Palavras Chave}

Gastroenterite eosinofílica · Ascite · Dor abdominal

\section{Case Report}

A 27-year-old male presented with diffuse abdominal pain and distention for 2 weeks. His medical history was notable of atopic asthma, rhinitis, and dust mite allergy. He was medicated with inhaled fluticasone $100 \mu \mathrm{g}$ (twice/day). He denied edema of the lips, tongue or palate, dysphagia, odynophagia, vomiting, diarrhea, or weight loss. There was no history of previously known food allergy, recent travelling abroad, or new medication.

His physical examination was significant for moderate ascites, and laboratory workup demonstrated leukocytosis $(14,600 / \mu \mathrm{L})$ with peripheral blood eosinophilia $(4,100 / \mu \mathrm{L})$ and elevated serum $\operatorname{IgE}(154 \mathrm{IU} / \mathrm{mL})$. C-reactive protein was only slightly elevated $(0.39 \mathrm{mg} / \mathrm{dL})$. His values of hemoglobin $(14.5 \mathrm{~g} / \mathrm{dL})$, albumin $(3.9$

\section{KARGER}

E-Mail karger@karger.com www.karger.com/pjg
C) 2016 Sociedade Portuguesa de Gastrenterologia Published by S. Karger AG, Basel

Karger

Open access

This article is licensed under the Creative Commons AttributionNonCommercial-NoDerivatives 4.0 International License (CC BYNC-ND) (http://www.karger.com/Services/OpenAccessLicense) Usage and distribution for commercial purposes as well as any distribution of modified material requires written permission. $\mathrm{g} / \mathrm{dL})$, erythrocyte sedimentation rate $(1 \mathrm{~mm})$, and liver enzymes were within normal ranges.

Abdominal ultrasound confirmed moderate ascites, and computed tomography enterography (fig. 1) showed diffuse thickening of the gastric and proximal small bowel wall (arrowheads) and peritoneal fluid (arrow). Ascitic fluid analysis after an abdominal tap revealed a serum-ascites albumin gradient $<1.1 \mathrm{~g} / \mathrm{dL}$ and significant eosinophilia (fig. 2, inset).

Esophagogastroduodenoscopy did not reveal significant endoscopic findings; however, transendoscopic gastric biopsies showed marked eosinophilic infiltration ( $>25$ eosinophils/high-powerfield magnification) (fig. 2). Esophageal biopsies did not show criteria for eosinophilic esophagitis. Imaging and pathology findings were, therefore, consistent with eosinophilic gastroenteritis (EGE).

Differential diagnosis including food allergy, parasitic infections, inflammatory bowel diseases, malignancy, and other eosinophilic disorders (such as Churg-Strauss syndrome and hypereosinophilic syndrome) [1] were taken into account. Extensive investigation (including allergen-specific serum IgE, skin-prick tests, stool examinations, colonoscopy with ileoscopy and biopsies, abdominal and thoracic CT-scan, peripheral blood smear, serum protein electrophoresis, electrocardiography, echocardiography and troponin levels, as well as consultations with hematology, immuno-allergology and ear, nose and throat doctors) ruled out these conditions.

Treatment with a course of oral prednisolone $(40 \mathrm{mg} /$ day for 7 days, then tapered by $5 \mathrm{mg} /$ week) resulted in peripheral blood eosinophil count normalization within $24 \mathrm{~h}$ and symptom resolution after 4 days. Since the patient was an adult, no food allergy was 


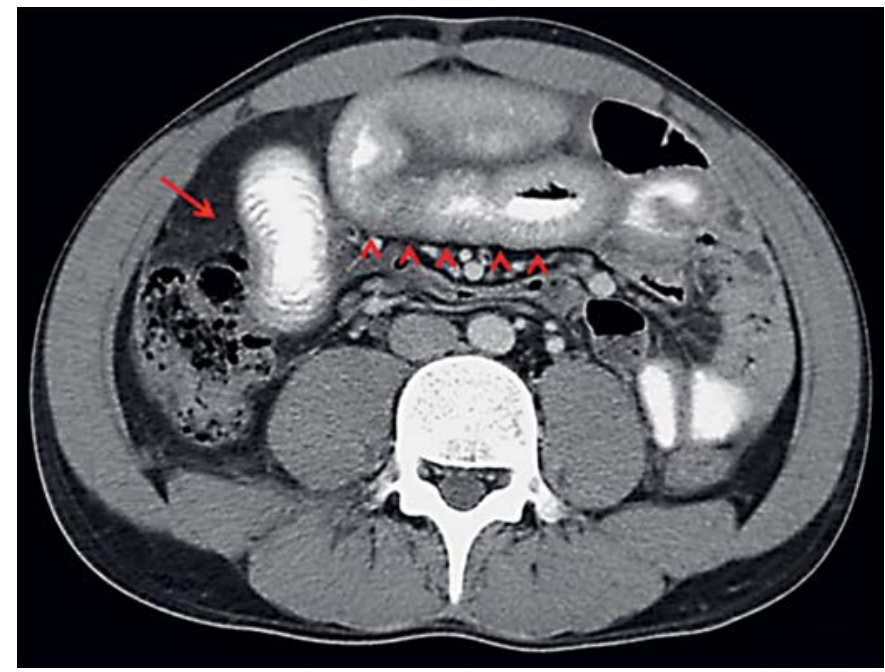

Fig. 1. Computed tomography enterography showing diffuse thickening of the gastric and proximal small bowel wall (arrowheads) and ascites (arrow).

found, and the criteria for eosinophilic esophagitis were not met. After a consultation with an immuno-allergology doctor, no dietary restrictions were advised. The patient remains asymptomatic after 2 years of follow-up.

\section{Discussion}

EGE is a rare, chronic inflammatory disease characterized by eosinophilic infiltration of the digestive tract. The etiology is unknown, but a personal or family history of food allergies and atopic disorders can be found in up to $50 \%$ of the cases [1].

The clinical features of EG vary depending on the location, extent, and depth of infiltration of the gastrointestinal wall. Eosinophilic ascites is an unusual form of presentation of EGE [2]. It is characteristic of the predominantly subserosal pattern of the disease (theleast common, followed by the intramural and the mucosal types) and is rare in young males [3]. However, even in the predominantly subserosal type, there is frequently significant mucosal and submucosal eosinophilic infiltration [1], which allows for the diagnosis to be obtained through transendoscopic biopsies in most cases.

The radiological appearance, the eosinophilic infiltrate, and frank improvement after steroid therapy confirm the diagnosis.

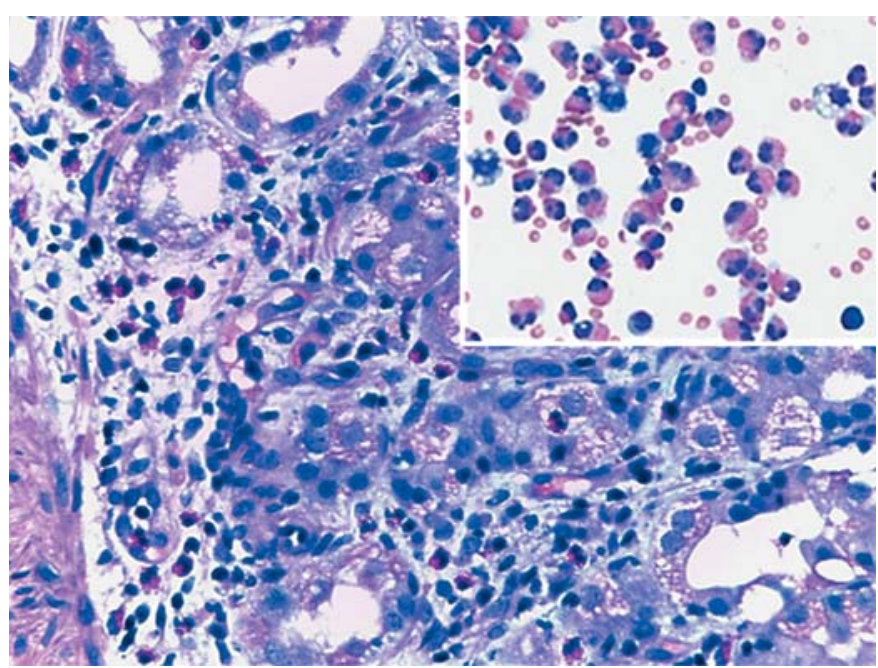

Fig. 2. Gastric biopsy specimen (hematoxylin and eosin, $\times 400$ ) showing intense eosinophilic infiltration ( $>25$ eosinophils/highpower-field magnification). Inset Ascitic fluid analysis revealing significant eosinophilia (Wright-Giemsa stain, $\times 600$ ).

The clinical course of EG is variable. Some patients have no recurrences, while others experience recurrent symptoms and require repeated or long courses of steroid therapy. In these patients, other therapies (mast cell inhibitors, antihistamines, or leukotriene receptor antagonists) may be considered [4]. According to previous studies, the predominantly serosal pattern of EG seems to have a good prognosis, with excellent response to steroids and presenting mainly with a single flare and no chronic course [5].

\section{Authors' Contribution}

L.C. Lourenço collected data and wrote the manuscript. D.V. Horta was responsible for the interpretation of data and manuscript editing. J. Reis was responsible for study supervision and manuscript reviewing.

\section{Statement of Ethics}

Patient consent was obtained for the publication of the case details.

\section{Disclosure Statement}

The authors have no conflicts of interest to disclose.

GE Port J Gastroenterol 2017;24:206-208 
References
1 Talley NJ, Shorter RG, Phillips SF, et al: Eosinophilic gastroenteritis: a clinicopathological study of patients with disease of the mucosa, muscle layer, and subserosal tissues. Gut 1990;31:54-58.

2 Zhang MM, Li YQ: Eosinophilic gastroenteritis: A state-of-the-art review. J Gastroenterol Hepatol 2016, Epub ahead of print.
3 Durieu I, Nove-Josserand R, Cathebras P, Durand DV, Rousset $\mathrm{H}$, Levrat R: Eosinophilic ascites. 2 new case reports (in French). Rev Med Interne 1992;13:446-448.

4 Straumann A: Idiopathic eosinophilic gastrointestinal diseases in adults. Best Pract Res Clin Gastroenterol 2008;22:481-496.

5 Pineton de Chambrun G, Gonzalez F, Canva JY, et al: Natural history of eosinophilic gastroenteritis. Clin Gastroenterol Hepatol 2011; 9:950-956. 